\title{
Chemical, Microbiological, Rheological and Sensory Properties of Yoghurt Fortified with Selenium
}

\author{
Osman, A.H. ' ; M.A. Mohran' ${ }^{2}$ W.I. El-Dosoki ${ }^{1}$ and A.A. Tammam ${ }^{2}$
}

${ }^{1}$ Dairy Department, Faculty of Agriculture, Al-Azhar University, Assiut, Egypt

${ }^{2}$ Dairy Department, Faculty of Agriculture, Assiut University, Assiut, Egypt

Received on: 24/12/2019

Accepted for publication on: 16/1/2020

\begin{abstract}
Selenium (Se) is a trace element that is essential to human life. The present study was conducted to study the use of three levels of (Se) in manufacture of yoghurt as follows: $0.2,0.4$ and $0.6 \mathrm{ppm}$ treatments were coded $\mathrm{T}_{1}, \mathrm{~T}_{2}$ and $\mathrm{T}_{3}$ respectively. Beside of previous treatments control sample was carried out (without $\mathrm{Se}$ addition). The resultant products were stored at $6 \pm 2 \mathrm{C}^{\circ}$ up to 10 days. All treatments subjected to chemical, microbiological, physical, rheological and organoleptic assessment. Results indicated that TS, TN and titratable acidity were slight increased with increasing the ratio of (Se), while the fat content is not affected. In samples at $0.6 \mathrm{ppm}(\mathrm{Se})$, it found a slight decrease in titratable acidity. During the cold storage for 10 days, the curd firmness and the density in all treatments had been increased, while the syneresis was decreased compared to control samples. Data also revealed that Lactobacilli and Streptococci counts increased with increasing the levels of (Se), but coliform bacteria were not detected in all treatments during the cold storage. The obtained data concluded that addition of (Se), up to $0.4 \mathrm{ppm}$ can be need in the manufacture of yoghurt without objectionable effect on the organoleptic properties.
\end{abstract}

Keywords: Yoghurt, trace elements, sodium selenite $\left(\mathrm{Na}_{2} \mathrm{SeO}_{3}\right)$.

\section{Introduction}

Trace elements function an important role as a cofactor for certain enzymes implicated in metabolism and cell development, most of them implicated in the metabolism of proteins, carbohydrates, lipids, and energy. They are also necessary for growth, development, muscle and nerve function, normal cellular functioning, and synthesis of some hormones and connective tissue. As a role antioxidant and benefit from the therapeutic properties of many diseases and also create effective treatment modalities (Al-Fartusie and Mohssan, 2017).

Trace elements account for $4 \%$ of total body lump and fraction of every tissue, liquid, cell and organ in human body. There is a sufficient evidence that metals, both independently or in proper equation with other metals, have structurally, biochemical and nutritional functions that are very significant for comprehensive human health, both mental and physical (Vahčić et al., 2010). Furthermore, trace elements occur in milk and dairy products as inorganic ions and salts, as well as part of organic molecules, such as proteins, fats, carbohydrates and nucleic acids. The chemical form of mineral elements is important because it determines their absorption in the intestine and their biological utilization. The mineral composition of milk is not constant 
because it depends on lactation phase, nutritional status of the animal, and environmental and genetic factors (Zamberlin et al. 2012). Studies have confirmed that $70 \%$ of men and $80 \%$ of women consumed foods that have less than two-thirds of one or more essential minerals and vitamins (Redmon, 1999). Fish and other seafood are the main sources of Se but cereals, meat, nuts, onion, garlic, mushroom, and eggs are also important dietary sources of Se. Foods as fruit, vegetables, milk, milk products, and drinks are the poorest sources of Se (Maihara et al., 2004). In addition, $\mathrm{Se}$ is an essential nutrient for all living organisms. Under appropriate conditions lactic acid bacteria (LAB) are capable for accumulating large amounts of trace elements, such as Se, and incorporating them into organic compounds. (Pieniz et al., 2017). The inorganic and organic Se forms in dietary supplements are metabolized differently in animals. Organic Se, such as Se-Met, is actively transported through and absorbed in the intestine and nonspecifically incorporated into body proteins in place of Met during protein synthesis, providing a means of reversible Se storage in organs and tissues. (Schrauzer, 2003) produced kefir and yoghurt; cheese produced with different technologies, butter and butter creams from milk with high Se content, and examined how the Se passes from the milk to the various dairy products. The possible to produce milk and dairy products with high Se content in order to better supply the population with healthy Se sources. In addition, the role of Se in the prevention of a number of degenerative diseases including cancer, inflammatory diseases, thyroid disorders, cardiovascular diseases, neurological diseases, Alzheimer's disease, infertility and infections has been documented (Csapó et al., 2015). Also, the current investigation is an attempt to study the toxicity of three heavy metals, Al, $\mathrm{Cd}$ and $\mathrm{Pb}$ adult, male and female white mice that have adverse effects on the reproductive capacity of mice and their teratogenicity effects and the protective role of $\mathrm{Se}$, as enriched Ras cheese when administered jointly with them (Abd El Monem, 2018).

The aim of this work was to fortified yoghurt with Se, without using it as feed additives in animal rations. The fortification method no affected the different strains of bacterial which used and to improve the daily Se requirements for consumer. Therefore we can fortify the yoghurt with Se as a role antioxidant and benefit from the therapeutic properties of many diseases and without the affected occurrence of undesirable changes in the product.

\section{Materials and Methods Materials:}

All chemicals used in this study were of analytical grade supplied by BDH, Sigma chemical companies.

Buffalo's milk was obtained from the herd of the Animal Production Department, Faculty of Agriculture, Al-Azhar University (Branch of Assiut).

Skim milk was obtained from whole fresh buffalo's milk by defatted cream using the laboratory centrifuge at $3000 \mathrm{xg}$ for $10 \mathrm{~min}$ at $20^{\circ} \mathrm{C}$.

\section{Starters:}

The following bacteria strains were used in our experiments: Lacto- 
bacillus delbrueckii subsp bulgaricus (EMCC 11102) and Streptococcus thermophilus (EMCC 11044) was obtained from Cairo Microbiological Resource Center (MIRCEN), Faculty of Agriculture, Ain Shams University. The bacteria were maintained by sub culturing in Skim milk medium.

\section{Se element:}

Sodium Selenite $\left(\mathrm{Na}_{2} \mathrm{OSe}_{3}, \mathrm{M}\right.$. W. 172.95 , Purity $99.5 \%$ ) were purchased from Electro Scient Chemical Company, Kasr El-Eieny, Cairo.

\section{Methods:}

\section{Experimental procedure:}

Manufacture of yoghurt:

Reduced fat buffalo milk (3\% fat) was divided into four equal portions, were as following:

C: Control yoghurt was made without $\mathrm{Na}_{2} \mathrm{SeO}_{3}$.

$\mathbf{T}_{1}$ : yoghurt was made adding 0.2ppm, $\mathrm{Na}_{2} \mathrm{SeO}_{3}$.

$\mathbf{T}_{2}$ : yoghurt was made adding $0.4 \mathrm{ppm}$, $\mathrm{Na}_{2} \mathrm{SeO}_{3}$.

$\mathbf{T}_{3}$ : yoghurt was made adding $0.6 \mathrm{ppm}$, $\mathrm{Na}_{2} \mathrm{SeO}_{3}$.

Reduced fat buffalo milk (3\% Fat)

Divided into four equal portions`

Heat treatment

(At $90^{\circ} \mathrm{C} \pm 1{ }^{\circ} \mathrm{C}$ for $15 \mathrm{~min}$ and cooling to $\left.42-44^{\circ} \mathrm{C}\right)$

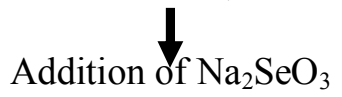

(T1, T2 and T3), Plus the control with-

Inoculated with $2 \%$ active mixed grow-

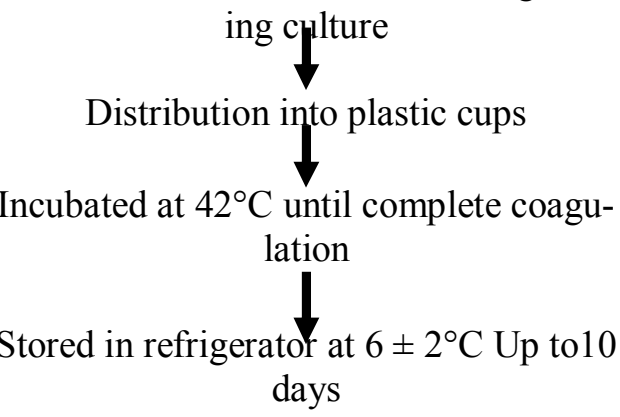

Each part was inoculated with $2 \%$ active growing culture (mixed 1:1 Lactobacillus delbrueckii subsp bulgaricus (EMCC 11102) and Streptococcus thermophilus (EMCC 11044), according to (Tawfik et al. 2003). $\mathrm{Na}_{2} \mathrm{SeO}_{3}$ ratios were added to each fraction and the Inoculated milk of each portion was equally distributed into plastic cups $(100 \mathrm{ml})$ incubated the mixture at $42^{\circ} \mathrm{C}$ until complete coagulation. After coagulation, samples were kept in the refrigerator at $6 \pm 2^{\circ} \mathrm{C}$. The samples were tested when fresh and after 3, 7 and 10 days of storage period.

\section{Chemical analyses:}

Total solids (TS) and Titratable acidity were adopted according to A.O.A.C (2000). The $\mathrm{pH}$ values were measured and $\mathrm{pH}$ values for different milk products samples using a $\mathrm{pH}$ meter model STARTER 300, OHAUS USA. Total nitrogen (T.N) content of products was determined by the semi-micro kjeldahl as described by IDF (1993). Fat contents determined in milk and products by the conventional Gerber's method as described by Ling (1963). Se content of the digested samples was determined by inductively coupled plasma optical emission spectrophotometer (ICP-OES) (Perkin Elmer Ltd., Optima 3300 DV, USA) as described by Prokisch, et.al. (2006), Curd firmness was determined by using the penetration method described by Shalabi (1987). Determination of syneresis one hundred grams of sample was placed on a filter paper resting on a top of a funnel. After 2 hours of drainage at $7^{\circ} \mathrm{C}$, the quantity of whey collected in a $50 \mathrm{ml}$ graduated cylinder was used as in index of syneresis 
Farooq and Haque (1992). Density was calculated using the regular equation as follows:-

$$
\text { Density }\left(\mathrm{g} / \mathrm{cm}^{3}\right)=\frac{\text { Weight }}{\text { Volume }}
$$

Total bacterial count, Coliform and Yeast \& Moulds of samples were determined according to Marshall (1992). Lactobacilli count and Streptococci count was estimated on the selective medium for lactobacilli MRS and M17 agar medium respectively, as suggested by (IDF, 1997). The plates were incubated at $37^{\circ} \mathrm{C}$ for 48 hours.

The organoleptic evaluation of resultant yoghurt was evaluated according to the method of Khodear $e t$ al. (2018) when fresh, 3, 7 and 10 days of stored at $6 \pm 2{ }^{\circ} \mathrm{C}$.

\section{Results and Discussion}

In this present investigation attempts have been made of yoghurt fortification with different doses of $\mathrm{Na}_{2} \mathrm{SeO}_{3}$, method was different levels (T1, T2 and T3) for yoghurt fortified with Se before the incubation of milk. The resultant Se-enriched yoghurt was stored at $6 \pm 2^{\circ} \mathrm{C}$ up to 10 days. The obtained final products were evaluated for its chemical, microbiological analysis rheological properties and sensory evaluation.

The chemical composition of yoghurt fortified with Se:

Data presented in Table 1 illustrate the chemical composition of Seenriched yoghurt made with different levels of $\mathrm{Na}_{2} \mathrm{SeO}_{3}$, during storage periods at $6 \pm 2^{\circ} \mathrm{C}$ up to 10 days.

Table 1. Chemical properties of yoghurt Fortified with Se during storage period at refrigerator temperature $6 \pm 2^{\circ} \mathrm{C}$ up to 10 days.

\begin{tabular}{|c|c|c|c|c|c|}
\hline \multirow{2}{*}{$\begin{array}{c}\text { Chemical } \\
\text { properties }\end{array}$} & \multirow{2}{*}{ Storage (days) } & \multirow{2}{*}{ Control } & \multicolumn{3}{|c|}{ Se-enriched yoghurt } \\
\cline { 4 - 6 } & & & T1 & T2 & T3 \\
\hline \multirow{3}{*}{ TS \% } & Fresh & 14.4 & 14.8 & 14.9 & 14.9 \\
& 3 & 14.6 & 15.0 & 15.5 & 15.7 \\
& 7 & 15.2 & 15.3 & 15.7 & 15.9 \\
& 10 & 15.5 & 15.7 & 16.0 & 16.2 \\
\hline \multirow{3}{*}{ Fat \% } & Fresh & 3.01 & 3.01 & 3.01 & 3.01 \\
& 3 & 3.01 & 3.02 & 3.02 & 3.02 \\
& 7 & 3.00 & 3.02 & 3.02 & 3.01 \\
Acidity \% & 10 & 3.01 & 3.02 & 3.01 & 3.01 \\
& Fresh & 0.64 & 0.64 & 0.63 & 0.60 \\
& 3 & 0.67 & 0.66 & 0.64 & 0.62 \\
& 7 & 0.70 & 0.68 & 0.67 & 0.64 \\
pH & 10 & 0.73 & 0.72 & 0.71 & 0.68 \\
\hline & Fresh & 4.52 & 4.51 & 4.53 & 4.53 \\
& 3 & 4.39 & 4.39 & 4.45 & 4.49 \\
& 7 & 4.33 & 4.37 & 4.40 & 4.44 \\
TN \% & 10 & 4.32 & 4.33 & 4.39 & 4.46 \\
\hline & Fresh & 0.82 & 0.83 & 0.84 & 0.84 \\
& 3 & 0.83 & 0.85 & 0.85 & 0.86 \\
& 7 & 0.84 & 0.85 & 0.87 & 0.90 \\
& 10 & 0.85 & 0.87 & 0.89 & 0.92 \\
\hline
\end{tabular}


Data in Table (1) revealed that, the total solids (TS) content of Seenriched yoghurt was affected by addition of different levels of $\mathrm{Na}_{2} \mathrm{SeO}_{3}$ and during storage periods at refrigerator temperatures up to 10 days. The TS content of Se rich yoghurt found to be increase with increasing the storage periods up to 10 days in all treatments. The yoghurts fortified with Se have better water holding capacities harmony with of Achanta et al. (2007).

The control sample had lower value of TS than that of other treatments. This may be among yoghurts fortified with Se, casein and whey protein correlates with Se because it can replace sulfur in sulfurcontaining amino acids Hekmat and McMahon (1997).

The presented data in the same Table revealed that, addition of different levels of $\mathrm{Na}_{2} \mathrm{SeO}_{3}$ had no affect on fat contents during storage periods at refrigerator temperature up to 10 days in Se-enriched yoghurt and control treatment. On the other hand, there was no affected in fat content in Se-enriched yoghurt samples compared to the control.

The effect addition of $\mathrm{Na}_{2} \mathrm{SeO}_{3}$ levels on the titratable acidity and $\mathrm{pH}$ values of Se-enriched yoghurt during storage periods at refrigerator up to 10 days shows in Table (1). It could be noticed that, titratable acidity behaves the opposite trend of $\mathrm{pH}$.

The data demonstrated that the acidity percent and $\mathrm{pH}$ values are increase and decrease with increasing of storage periods up to 10 days at refrigerator temperatures in all treatments, respectively. On the other hand, the data showed that the acidity percent were decrease ineffective with increasing of $\mathrm{Na}_{2} \mathrm{SeO}_{3}$ levels. These results are in harmony with those of (Alzate et al., 2010; Zommara and Prokisch, 2015) who reported that there is a decrease in acidity of milk fortified with Se with no significant change in its properties compared to the control.

The presented data in Table (1) revealed that a slightly increase the total nitrogen percentages of Seenriched yoghurt up to the end of storage periods at refrigerator temperature in all treatments. In addition, found the total nitrogen percentages of Se-enriched yoghurt ineffective with increasing of $\mathrm{Na}_{2} \mathrm{SeO}_{3}$ levels in most treatments.

Moreover, the obtained data showed that control samples had relatively low values of total nitrogen than that of Se-enriched yoghurt samples.

\section{Determination of Total Se in Se- enriched yoghurt and control sam- ple:}

The presented data in Fig (1) showed that, the values of total $\mathrm{Se}$ concentration in milk used in manufacture of yoghurt, control yoghurt samples (without Se) and Se-enriched yoghurt. The analyzed data showed that the mean values, found decrease highly in control yoghurt samples on the first day and during 10 day storage at $6 \pm 2{ }^{\circ} \mathrm{C}$ were to be 1.87 and $1.85 \mu \mathrm{g} / 100 \mathrm{~g}$ respectively, made from milk with $1.68 \mu \mathrm{g} / 100 \mathrm{~g}$ Se content. A similar trend was observed in yoghurts and milk Pechova et al. (2008) the Se contents in yoghurts and milk were $\quad 17.13 \pm 5.40 \mu \mathrm{g} . \mathrm{kg}^{-1}$ and $13.14 \pm 4.21 \mu \mathrm{g} .1-1$ respectively. These results are highest then the values of 
Tammam, et al. (2012), Holland et al. (1995) and Cashman (2002) were the average content of Se $2.0 \mu \mathrm{g} / 100 \mathrm{~g}$ in yoghurt. Al-Othman et al. (2012) found the Se content in yoghurt 2.0 $\mu \mathrm{g} / \mathrm{kg}$.

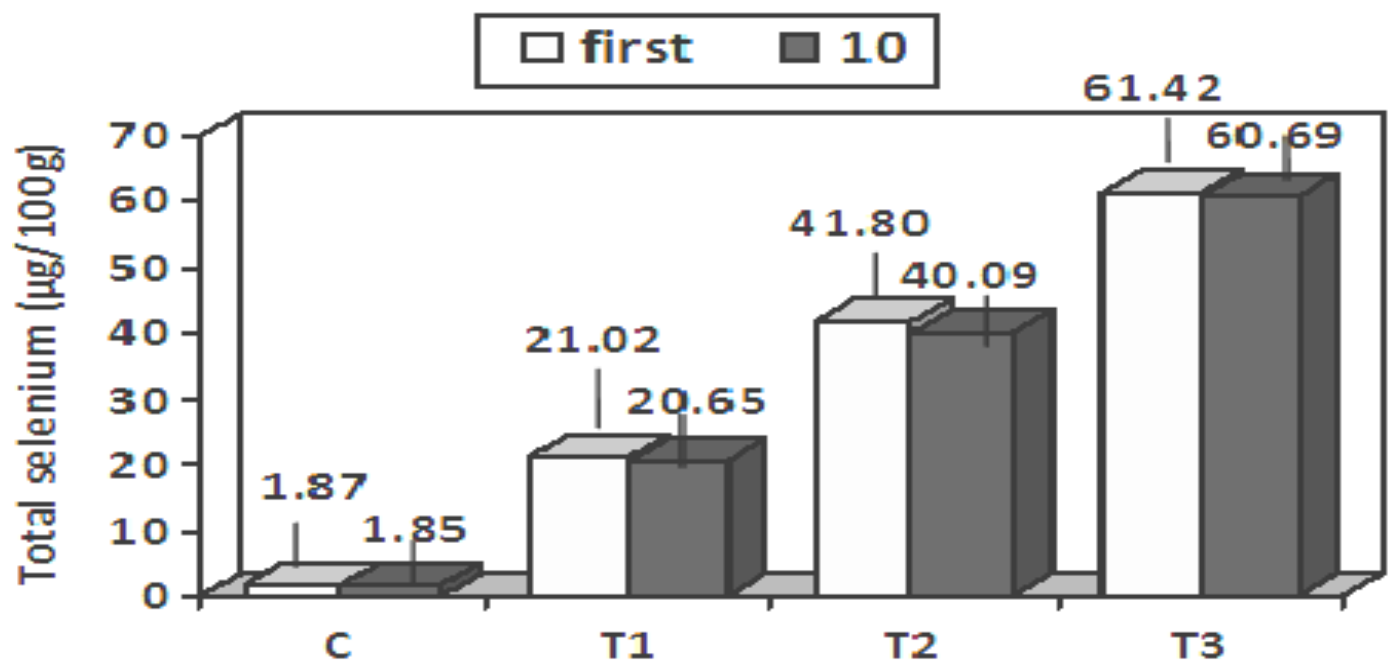

Fig. 1. Clear the total $\mathrm{Se}(\mu \mathrm{g} / 100 \mathrm{~g})$ in Se-enriched yoghurt and control yoghurt Samples on the first day and after 10 day storage at $6 \pm 2^{\circ} \mathrm{C}$.

On the other hand, the data revealed that the gradual addition of levels $\mathrm{Na}_{2} \mathrm{SeO}_{3}$ led to gradual increased total $\mathrm{Se}$ values in treated samples compared to control in both fresh and after 10 days of storage at $6 \pm 2{ }^{\circ} \mathrm{C}$ in all treatments.

The physical and rheological properties of yoghurt fortified with Se during storage:

The presented data in Table 2 showed that the addition of $\mathrm{Na}_{2} \mathrm{SeO}_{3}$ levels led to gradual increase in the curd firmness of Se-enriched yoghurt. So, addition of $\mathrm{Na}_{2} \mathrm{SeO}_{3}$ levels im- parted Se-enriched yoghurt with higher curd firmness than that in the control yoghurt. Moreover, the values of curd firmness found to increase with increasing storage periods at refrigerator temperature up to 10 days in all treatments. Also, gradual increase with increasing of $\mathrm{Na}_{2} \mathrm{SeO}_{3}$ levels in all treatments. This might be due to the increase in water holding capacity of the curd mass as it affects the protein interaction during coagulation process, resulting into less yield of syneresis Achanta et al. (2007). 
Table 2. Some physical and rheological properties of yoghurt fortified with Se during storage period at $6 \pm 2^{\circ} \mathrm{C}$ up to 10 days.

\begin{tabular}{|c|c|c|c|c|c|}
\hline \multirow[t]{2}{*}{ Components } & \multirow{2}{*}{$\begin{array}{c}\text { Storage } \\
\text { (days) }\end{array}$} & \multirow[t]{2}{*}{ Control } & \multicolumn{3}{|c|}{$\begin{array}{c}\text { Se-enriched } \\
\text { yoghurt }\end{array}$} \\
\hline & & & \begin{tabular}{|l|} 
T1 \\
\end{tabular} & T2 & T3 \\
\hline \multirow{4}{*}{$\begin{array}{l}\text { Syneresis } \\
(\mathrm{ml} / 100 \mathrm{gm})\end{array}$} & resh & 31.9 & 30.8 & 30.3 & 30.1 \\
\hline & 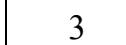 & 35.8 & 32.3 & 31.7 & 30.6 \\
\hline & 7 & 37.6 & 33.6 & 32.7 & 31.3 \\
\hline & 10 & 39.3 & 36.5 & 33.8 & 32.7 \\
\hline \multirow{4}{*}{$\begin{array}{c}\text { Firmness } \\
\text { (gm) }\end{array}$} & Fresh & 15.2 & \begin{tabular}{|l|l|}
15.9 \\
\end{tabular} & 16.5 & \begin{tabular}{|l|l|}
16.7 \\
\end{tabular} \\
\hline & 3 & 17.3 & 18.0 & 18.5 & 18.8 \\
\hline & 7 & 18.1 & 18.9 & 19.2 & 19.4 \\
\hline & 10 & 18.4 & 19.8 & 20.1 & 20.3 \\
\hline \multirow{4}{*}{$\begin{array}{c}\text { Density } \\
\left(\mathrm{gm} / \mathbf{c m}^{3}\right)\end{array}$} & Fresh & 1.22 & 1.23 & 1.24 & 1.26 \\
\hline & 3 & 1.24 & 1.25 & 1.26 & 1.27 \\
\hline & I & 1.25 & 1.26 & 1.28 & 1.29 \\
\hline & 10 & 1.28 & 1.29 & 1.30 & 1.32 \\
\hline
\end{tabular}

On the other hand, the data revealed that the gradual addition of $\mathrm{Na}_{2} \mathrm{SeO}_{3}$ levels led to gradual decrease in the syneresis of Se-enriched yoghurt and the values of syneresis in the control sample were higher than that treated samples. These results are in harmony with of Achanta et al. (2007) reported that The mean syneresis values of yoghurts fortified with iron, Se and magnesium were significantly $(\mathrm{P}<0.05)$ lower than the control yoghurt. This indicates that yoghurts fortified with Se, magnesium and iron has better water holding capacities. Pehrson (1993) reported that Se when combined with Vitamin $\mathrm{E}$ and glutathione peroxidase improved the integrity of the cell membranes in pork, thereby reducing moisture loss from the cell. In addition, the values of syneresis were increase with increasing storage period up to 10 days in all treatments. This may be explained by the decrease in pH during storage Kosikowski (1982) which may have had contracting effect on the casein micelle matrix causing more serum to be released. Similar, observations of low syneresis initially followed by increased syneresis over an increased storage was observed by Farooq (1997) and Ji (2000).

The obtained data in the same Table revealed that the density was slightly higher in Se-enriched yoghurt sample than that in the control yoghurt. In addition, the values of density were slight increasing with increasing storage period up to 10 days, and increase addition of $\mathrm{Na}_{2} \mathrm{SeO}_{3}$ levels in all treatments. These results are in harmony with of Achanta et al. (2007) they reported that the apparent viscosity of yoghurts fortified with minerals did not vary significantly $(\mathrm{P}<0.05)$ when compared to the control.

Generally, the Se-enriched yoghurt was slightly increased than control for firmness as well as density and slightly less syneresis. However, curd firmness, density and syneresis are increase through the storage periods till 10 days at refrigerator temperatures of all treatments. So, when addition of $\mathrm{Na}_{2} \mathrm{SeO}_{3}$ levels for yoghurt gave best results of some physical and rheological properties.

The microbiological properties of yoghurt fortified with Se:

The presented data in Table 3 showed that total bacterial, Lactobacilli and Streptococci and Yeast \& Moulds counts of Se-enriched yoghurt were influenced by addition of $\mathrm{Na}_{2} \mathrm{SeO}_{3}$ during kept at $6 \pm 2{ }^{\circ} \mathrm{C}$ up to 10 days.

The total viable bacterial counts found to slightly increase up to 3 days and then slightly decrease up to the end of storage periods in all treatments. In addition, there were slight decreases of total bacterial counts 
with increasing of $\mathrm{Na}_{2} \mathrm{SeO}_{3}$ levels in most treatments.

However, total bacterial counts of Se-enriched yoghurt were higher than that of control samples. These results are in accordance with those reported by Hashim (2007) and Salman et al., (2012).

Table 3. Counts of some microbial groups (Log cuf/gm) of yoghurt fortified with Se during storage period at $6 \pm 2^{\circ} \mathrm{C}$ up to 10 days.

\begin{tabular}{|c|c|c|c|c|c|}
\hline \multirow{2}{*}{$\begin{array}{c}\text { Microbial } \\
\text { type }\end{array}$} & \multirow{2}{*}{$\begin{array}{c}\text { Storage } \\
\text { (days) }\end{array}$} & \multirow[t]{2}{*}{ Control } & \multicolumn{3}{|c|}{$\begin{array}{l}\text { Se-enriched } \\
\text { yoghurt }\end{array}$} \\
\hline & & & T1 & $\mathbf{T 2}$ & T3 \\
\hline \multirow{4}{*}{$\begin{array}{c}\text { Total } \\
\text { bacterial } \\
\text { count }\end{array}$} & Fresh & 9.24 & 9.24 & 9.27 & 9.29 \\
\hline & 3 & 9.26 & 9.29 & 9.31 & 9.33 \\
\hline & 7 & 9.25 & 9.26 & 9.29 & 9.32 \\
\hline & 10 & 9.22 & 9.24 & 9.26 & 9.26 \\
\hline \multirow{4}{*}{$\begin{array}{l}\text { Lactobacilli } \\
\text { count }\end{array}$} & Fresh & 7.72 & 7.60 & 7.72 & 7.82 \\
\hline & 3 & 7.80 & 7.78 & 7.79 & 7.83 \\
\hline & 7 & 7.78 & 7.73 & 7.73 & 7.80 \\
\hline & 10 & 7.78 & 7.72 & 7.73 & 7.80 \\
\hline \multirow{4}{*}{$\begin{array}{l}\text { Streptococci } \\
\text { count }\end{array}$} & Fresh & 7.79 & 7.73 & 7.82 & 7.90 \\
\hline & 3 & 7.64 & 7.51 & 7.62 & 7.73 \\
\hline & 7 & 7.88 & 7.47 & 7.59 & 7.66 \\
\hline & 10 & 7.65 & 7.45 & 7.57 & 7.62 \\
\hline \multirow{4}{*}{$\begin{array}{c}\text { Yeasts \& } \\
\text { Moulds count }\end{array}$} & Fresh & ND & ND & ND & ND \\
\hline & 3 & ND & ND & ND & ND \\
\hline & 7 & 2.36 & 2.21 & 2.10 & 1.80 \\
\hline & 10 & 3.69 & 3.12 & 3.00 & 2.63 \\
\hline $\begin{array}{c}\text { Coliform } \\
\text { bacteria } \\
\text { group }\end{array}$ & \multicolumn{5}{|c|}{ ND* } \\
\hline
\end{tabular}

* Not- detected

Also, showed approximately similar pattern for counts of Lactobacilli found to slightly increase up to 3 days and slightly decrease in the end of storage periods of control samples and all treatments. In addition, there were slight increases of Lactobacilli and Streptococci counts with increasing of $\mathrm{Na}_{2} \mathrm{SeO}_{3}$ levels in some of Seenriched yoghurt samples, and with progressing of storage periods up to 10 days in some treatments. These results are agreement with those previously reported by (Xia et al., 2007) and (Alzate et al., 2010).
Yeast and Moulds were not detected in fresh samples and after 3 days of storage in all treatments, there microorganisms appeared after 7 days and with progressing of storage periods up to 10 days of storage period in all treatments. In addition, their counts were decrease with increasing of $\mathrm{Na}_{2} \mathrm{SeO}_{3}$ levels in most treatments. This agreement with Yang et al., (2009) reported that the antibacterial activity of prebiotics with organic Se was nearly the same as that of the antibiotics group.

Additionally, the coliform bacteria were not found in all treatments, which this might be due to the severity of heat treatments of milk and preventive action of lactic acid bacteria and their metabolites on the growth of coliforms. These results are in harmony with those of Fayed et al. (2001); El-Nagar and Brennan (2001); Tammam et al. (2011).

The organoleptic properties of yoghurt fortified with Se during storage:

Data presented in Table 4 showed that the organoleptic properties of Se-enriched yoghurt were influenced by addition of $\mathrm{Na}_{2} \mathrm{SeO}_{3}$ levels during kept at $6 \pm 2{ }^{\circ} \mathrm{C}$ up to 10 days.

The data observed that, mean values of organoleptic scores within each treatment, were examined as mentioned in methodology. The control yoghurt had lower flavor than that of Se-enriched yoghurt at any $\mathrm{Na}_{2} \mathrm{SeO}_{3}$ levels after fresh and up to 10 days storage in all treatments. In addition, T2 had the superior flavor, while, T3 at 7 and 10 days storage had lower flavor than that in other treatments. These results are disagreement 
with those of Hekmat and McMahon (1997). Zhang and Mahoney (1991) reported that there were no significant differences in flavor scores among Se fortified yoghurt and control yoghurt.

Table 4. Organoleptic properties of yoghurt Fortified with Se during storage period at $6 \pm 2^{\circ} \mathrm{C}$ up to 10 days.

\begin{tabular}{|c|c|c|c|c|c|}
\hline \multirow{2}{*}{ Properties } & \multirow{2}{*}{$\begin{array}{c}\text { Storage } \\
\text { (days) }\end{array}$} & Control & \multicolumn{2}{|c|}{$\begin{array}{c}\text { Se-enriched } \\
\text { yoghurt }\end{array}$} \\
\cline { 5 - 7 } & & & T1 & T2 & T3 \\
\hline & Fresh & 44.0 & 45.0 & 46.2 & 45.4 \\
Flavor & 3 & 42.6 & 43.2 & 45.0 & 45.1 \\
$\mathbf{( 5 0 )}$ & 7 & 42.9 & 42.9 & 47.4 & 42.0 \\
& 10 & 42.4 & 42.4 & 43.9 & 42.9 \\
\hline Body \& & Fresh & 27.4 & 27.5 & 27.6 & 29.0 \\
Texture & 3 & 26.5 & 26.8 & 28.7 & 27.8 \\
$\mathbf{( 3 0 )}$ & 7 & 26.9 & 27.9 & 28.7 & 28.8 \\
& 10 & 26.2 & 27.1 & 27.3 & 27.3 \\
\hline Appearance & Fresh & 18.3 & 18.3 & 18.3 & 18.3 \\
and color & 3 & 18.9 & 18.8 & 19.0 & 18.8 \\
$\mathbf{( 2 0 )}$ & 7 & 18.2 & 18.5 & 18.7 & 18.7 \\
\hline & 10 & 18.4 & 18.4 & 18.5 & 18.6 \\
\hline Total score & Fresh & 89.7 & 90.8 & 92.1 & 92.7 \\
$\mathbf{( 1 0 0 )}$ & 7 & 88.0 & 88.8 & 92.7 & 91.7 \\
& 10 & 88.0 & 89.3 & 94.8 & 89.5 \\
& & 87.0 & 87.9 & 89.7 & 88.8 \\
\hline
\end{tabular}

As regarded to body and texture, the data showed that Seenriched yoghurt gained variable scores for body \& texture and obvious interactions between Se add and storage time on body and texture scores. The samples with high levels of $\mathrm{Na}_{2} \mathrm{SeO}_{3}$ had higher values than that in lower levels and control yoghurt samples. This may be a change in casein structure when Se binds to micellar casein. This probable change in the structure of casein may explain better water holding capacity/less released whey in Se fortified yoghurt or this might be due to the unseparated of whey at high level of $\mathrm{Na}_{2} \mathrm{SeO}_{3}$ levels and production of acids, to give the reduced coagulation and forma- tion of soft and loose textured curd. These results are disagreement of Achanta. et al. (2007) reported that there were no significant differences in texture scores among Se fortified yoghurt and control yoghurt.

Regarding appearance and color of Se-enriched yoghurt were not affected by addition of $\mathrm{Na}_{2} \mathrm{SeO}_{3}$ levels in all treatments and control yoghurt samples. The storage of Se-enriched yoghurt and control yoghurt samples, Uninfluential in appearance and color during kept at $6 \pm 2{ }^{\circ} \mathrm{C}$ up to 10 days in all treatments. These results are in agreement with of Alzate et al., (2010) and Achanta et al. (2007) reported that there were no significant differences in appearance and color among Se fortified yoghurt and control yoghurt.

Minerals are known to alter dairy protein structure, reported that mineral salts alter the partitioning of the caseins between the colloidal and serum phases of milk and the ionic environment of the proteins. The minerals may have altered the casein micelle matrix structure of the yoghurts in such a way as to have contributed to the white opacity of the yoghurts leading to the increased values (Augustin, 2000).

The obtained data concluded that addition of (Se), up to $0.4 \mathrm{ppm}$ can be need in the manufacture of yoghurt without objectionable effect on the organoleptic properties.

\section{References}

Abd El Monem, M.A. (2018). Improving quality of low fat ras cheese. M.Sc. Thesis, Fac. Agric., Cairo AlAzhar. Univ., Egypt.

Achanta, K.; Aryana, K.J. and Boeneke, C.A. (2007). Fat free plain set yoghurts fortified with various min- 
erals.LWT-Food Science and Technology, 40(3). 424-429.

Al-Fartusie, F.S. and Mohssan, S.N. (2017). Essential trace elements and their vital roles in human body. Indian. J., Adv Chem Sci, 5(3): 127-136.

Al-Othman, A.M.; Al-Othman, Z.A.; ElDesoky, G.E.; Aboul-Soud, M.A.; Habila, M.A. and Giesy, J.P. (2012). Daily intake of selenium and concentrations in blood of residents of Riyadh City, Saudi Arabia. Environmental geochemistry and health, 34(4): 417-431.

Alzate, A.; Pérez-Conde, M.C.; Gutiérrez, A.M. and Cámara, C. (2010). Selenium-enriched fermented milk: A suitable dairy product to improve selenium intake in humans. International dairy journal, 20(11): 761-769.

Association of Official Analytical Chemists "A.O.A.C" (2000). Official Methods of Analysis of Association of Official Agric. Chemists. 17th Ed.Wisconsin: George Banta Co. Inc.

Augustin, M.A. (2000). Mineral salts and their effect on milk functionality. Australian Journal of Dairy Technology, 55(2), 61-64.

Cashman, K.D. (2002). Trace elements, Nutritional Significance. U: Roginski, H., Fuquay, J.W., Fox, P.F. (eds.) Encyclopedia of Dairy Sciences, No 3, London: Academic Press, 2059-2065.

Csapó, J.; Holló, G.; Holló, I.; Salamon, R.V.; Salamon, S.; Toró, S. and Kiss, Z.C. (2015). Production of selenium-enriched milk and dairy products. Acta Universitatis Sapientiae, Alimentaria, 8(1): 5-29.

El-Nagar, G.F. and Brennan, C.S. (2001). The influence of fiber addition on the texture and quality of stirred yoghurt. Proc. $8^{\text {th }}$ Egyptian
Conf. for Dairy Sci. and Tech., pp.: 505-523.

Farooq, H. and Haque, Z.U. (1992). Effect of sugar asters on the textural properties of nonfat low caloric yoghurt. J. Dairy Sci., 75: 26762680 .

Farooq, K. (1997). Effect of fat replacers on the physico-chemical properties of low fat and nonfat dairy products. Ph.D. Dissertation, Mississippi State University, (pp. 188).

Fayed, E.O.; Magdoub, M. N. I.; Hammad, A.A. and Meleigi, S. A. (2001). Use of microbial gum in some dairy products. Proc. $8^{\text {th }}$ Egyptian Conf. for Dairy Sci. and Tech., pp.: 481-493.

Hashim, I.B. (2007). Effect of cooling temperature and defrosting time on date quality during cold storage. The Seventh Annual U.A.E. University Res. Conference pp: 1-10.

Hekmat, S. and McMahon, D. (1997). Manufacture and quality of ironfortified yoghurt. Journal of Dairy Science. 80, 3114.

Holland, B.; Welch, A.A.; Unwin, I.D.; Buss, D.H.; Paul, A.A. and Southgate, D.A.T. (1995). The Composition of Foods, $5^{\text {th }}$ ed. London: Royal Society of Chemistry and Ministry of Agriculture, Fisheries and Food.

International Dairy Federation. IDF (1993). Milk. Determination of nitrogen content. Standard 20B. Brussels: International Dairy Federation.

International Dairy Federation. IDF (1997). Yoghurt. Enumeration of characteristic microorganisms. Colony count technique at $37^{\circ} \mathrm{C}$. Int. Dairy Federation Standard $117 \mathrm{~B}$.

$\mathrm{Ji}, \mathrm{T}$. (2000). Effect of dehydration process on physicochemical properties of jersey and mixed Cheddar whey protein concentrates and their ef- 
fect on the quality of dairy products. Ph.D. dissertation, Mississippi State University.

Xia, K. S.; Chen, L. and Quing Liang, J. (2007). Enriched selenium and its effects on growth and biochemical composition in Lactobacillus bulgaricus. Journal of Agricultural and Food Chemistry. 55, 24132417.

Khodear, M. M.; Zayan, F.A.; Tammam, A.A. and Mohran, A.M. (2018). Influence of Adding Inulin as a Fat Replaser on the Characteristics of Yoghurt. J. Food and Dairy Sci., Mansoura Univ., Vol. 9 (1): 13-17.

Kosikowski, F.V. (1982). Cheese and fermented milk foods. $2^{\text {nd }}$ Printing with revistions (1978).573.F.V.Kosikowski and Associates, P.O.139 Brooktondale, Ithaca. N. Y.USA.

Ling, E.R. (1963). A text Book of Dairy Chemistry. Vol. 2, practical, $3^{\text {rd }}$ edition publishers Chapman and Hall limited, London.

Maihara, V.; Gonzaga, I.; Silva, V.; Fávaro, D.; Vasconcellos, M. and Cozzolino, S. (2004). Daily dietary selenium intake of selected Brazilian population groups. Journal of Radioanalytical and Nuclear Chemistry, 259(3): 465-468.

Marshall, R.T. (1992). Standard methods for the examination of dairy products, $16^{\text {th }}$ ed. American Public Health Association Washington, D.C.

Official Methods of Analysis (AOAC) (2000). Official Methods Of Analysis, $15^{\text {th }}$ ed. Association Of Official Analytical Chemists, inc., USA.

Pechova, A.; Janstova, B.; Misurova, L.; Drackova, M.; Vorlova, L. and Pavlata, L. (2008). Impact of Supplementation of Various Selenium Forms in Goats on Quality and Composition of Milk, Cheese and
Yoghurt. ACTA VET. BRNO, 77: 407-414.

Pehrson, B. (1993). Selenium in nutrition with special reference to biopotency of organic and inorganic selenium compounds. Biotechnology in the Feed Industry, 71- 70.

Pieniz, S.; Andreazza, R.; Mann, M.B.; Camargo, F. and Brandelli, A. (2017). Bioaccumulation and distribution of selenium in Enterococcus durans. Journal of Trace Elements in Medicine and Biology, 40: 37-45.

Prokisch, J.; Szegvari, I.; Szeles, E.; Kovacs B. and Gyri, Z. (2006). Normalization method for evaluation of metal contamination of soil. Cereal Research Communication 34: 263-266.

Redmon, G.L. (1999). Minerals: What your body really needs and why. Garden city park, NY: Avery publishing group (pp. 17).

Salman, K.H.; Mansour, A.I.; Tammam, A.A. and El-Gazzar, F.E. (2012). Utilization of egg-shell powder as a calcium fortifier in stirred Dibis probiotic yoghurt. Assiut J. Agric. Sci., 43(1): 1-18.

Schrauzer, G.N. (2003). The nutritional significance, metabolism and toxicology of selenomethionine. Adv. Food Nutr. Res. 47:73-112.

Shalabi, S.I. (1987). Milk clotting activity of commercial rennet substitute. A comparative study. Minia Journal of Agric. Res. and Dev., 9: 441-460.

Tammam, A.A., Abd-El-Rahim, A.M. and Mohamed, T.H. (2011). Characteristics of low fat probiotic yoghurt. Assiut J. Agric. Sci. 42(5): 1-16.

Tammam, A.A.; Abd-El-Rahim, A.M. and Mohamed, T.H. (2012). Deterrmination and evaluation of heavy metals in colostrum and some dairy products. J. of Food 
and Dairy Sciences, Mansoura University, 3(12): 715-723.

Tawfik, N.F.; Sharaf, O.M.; Amin, G.A.; Khalafalla, G.M.; El-Gizawy, S.A. and Abdel-Khalek, A.B. (2003). Utilization of some microorganisms as dietary adjuncts III. Production and application. Egyptian Journal of Dairy Science, 31(2): 221-232.

Vahčić, N.; Hruskar, M.; Marković, K.; Banović, M. and Barić, I.C. (2010). Essential minerals in milk and their daily intake through milk consumption. Mljekarstvo/Dairy, 60(2).

Yang, J.; Huang, K.; Qin, S.; Wu, X.; Zhao, Z. and Chen, F. (2009). Antibacterial Action of SeleniumEnriched Probiotics Against
Pathogenic Escherichia coli. Institute of Nutritional and Metabolic Disorders, Nanjing Agricultural University, Nanjing, China; Dig Dis Sci, 54:246-254.

Zamberlin, S.; Antunac, N.; Havranek, J. and Samaržija, D. (2012). Mineral elements in milk and dairy products. Mljekarstvo: časopis za unaprjeđenje proizvodnje i prerade mlijeka, 62(2): 111-125.

Zhang, D. and Mahoney, A.W. (1991). Iron fortification of process cheddar cheese. Journal of Dairy Science, 74: 353-358.

Zommara, M. and Prokisch, J. (2015). Selenium rich yoghurt: biofortification for better health. Egyptian Journal of Dairy Science, 43(2): 159-167. 
الخو اص الكيميائية و الميكروبيولوجية والريولوجية والحسيه للزبادي المدعم بالسلينيوم

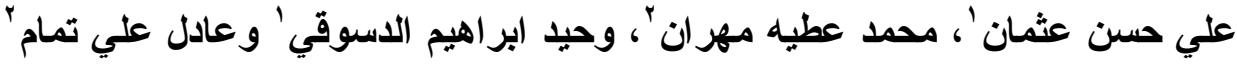

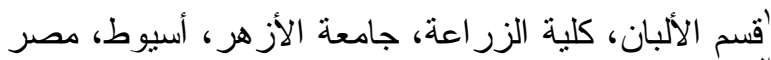

كَّم الألبان، كلية الزرانة الزراعة، جامعة أسيوط، أسبوط، أسيوط، مصر

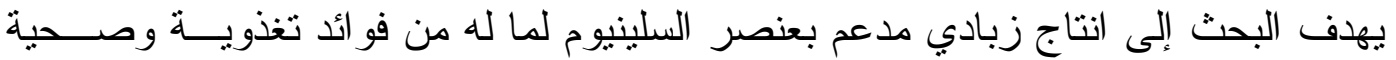

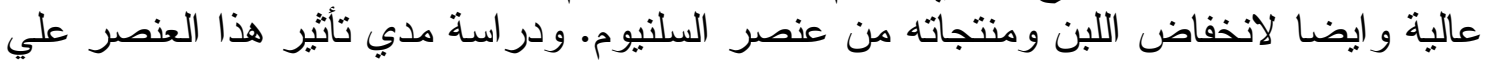

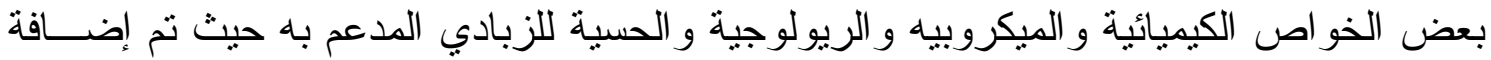

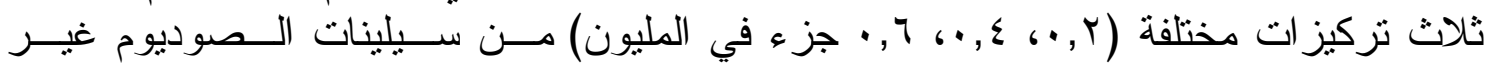

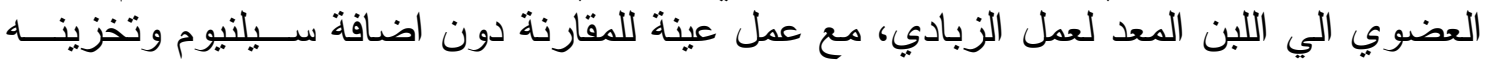

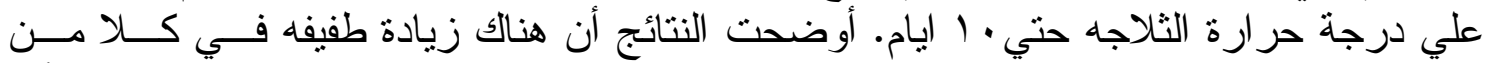

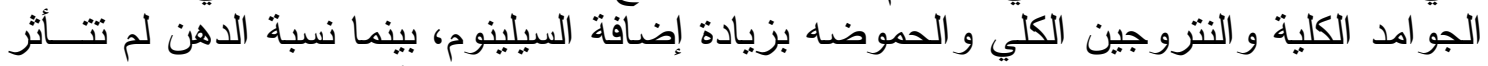

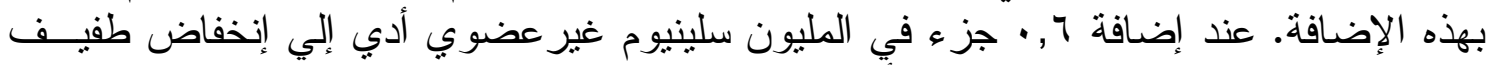

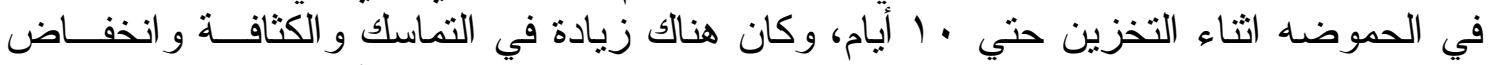

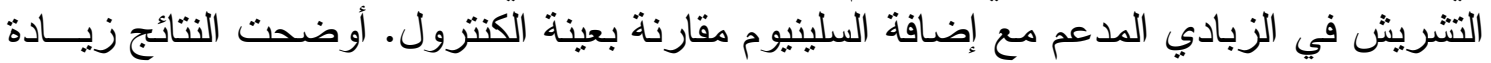

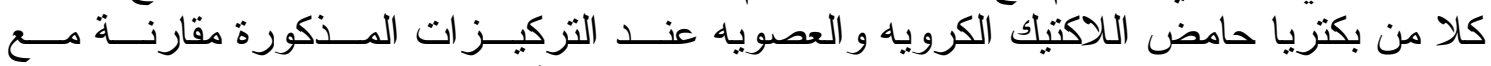

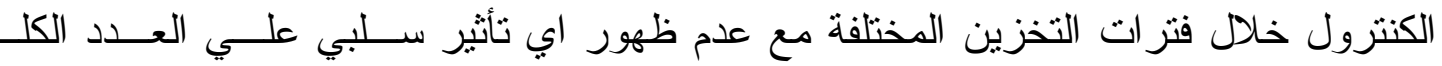

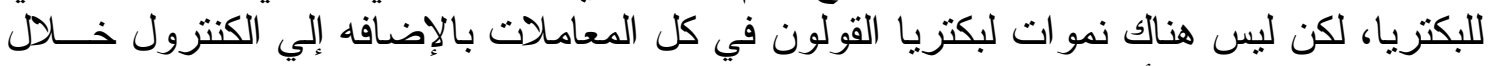

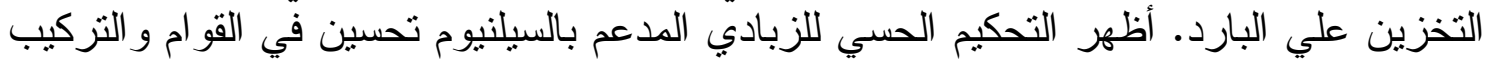

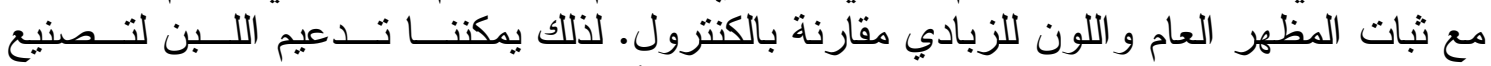

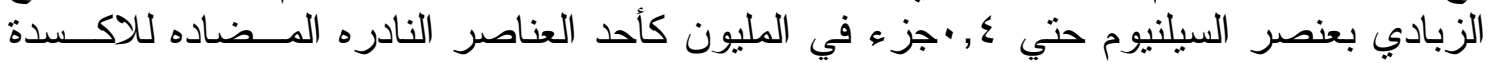

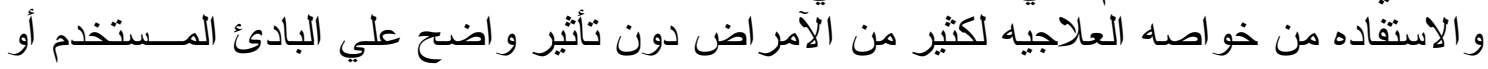

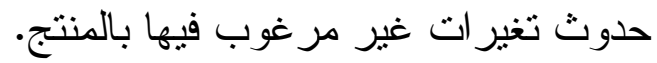

